\title{
Ecology of Mylesinus paucisquamatus Jégu \& Santos, 1988, an endangered fish species from the rio Tocantins basin
}

\author{
Oscar B. Vitorino Júnior, Carlos S. Agostinho and Fernando M. Pelicice ${ }^{1}$
}

Mylesinus paucisquamatus is a threatened fish endemic to the rio Tocantins basin, with little information about its natural history. Using monitoring data obtained between 1998 and 2009, we investigated the spatial distribution, feeding and reproduction of this species in a long stretch of the middle-upper rio Tocantins. Eighty-one individuals were captured over a decade of intensive sampling. In addition, we recorded the species in only 13 out of 35 sites, particularly in the Tocantins and Paranã rivers. Most individuals were captured alone, while the remaining formed small groups. These results indicate that this fish is rheophilic and rare. We recorded seasonal variation in fish abundance, with higher values during the dry season, indicating seasonal movements. The species is herbivorous and specialized in the consumption of plants attached to substrates, particularly bryophytes. We also observed seasonality in reproduction, since reproductive activity increased during the early dry season. These ecological traits, e.g., rarity, rheophilic and specialized feeding habits, indicates that $M$. paucisquamatus is vulnerable to environmental changes, particularly river damming. Considering that three large dams currently regulate and fragment this section of the rio Tocantins, the persistence of this species is jeopardized, demanding effective conservation actions.

Mylesinus paucisquamatus é um peixe endêmico da bacia do rio Tocantins, ameaçado de extinção mas com escassa informação sobre sua história natural. Usando dados de monitamentos obtidos entre 1998 e 2009, investigamos a distribuição espacial, ecologia alimentar e reprodução desta espécie em um longo trecho do médio-alto rio Tocantins. Um total de 81 indivíduos foi capturado em mais de uma década de monitoramento. Além disso, a espécie ocorreu em apenas 13 dos 35 locais monitorados, principalmente nos canais dos rios Tocantins e Paranã. A maior parte dos indivíduos foi capturado sozinho, enquanto que os demais foram capturados em pequenos grupos (dois a cinco indivíduos). Tais resultados indicam que a espécie é reofílica e rara. Registramos variação sazonal de abundância, com valores mais elevados durante a estiagem, o que indica deslocamentos sazonais. A espécie é herbívora e especializada no consumo de plantas ancoradas em substratos, particularmente briófitas. A reprodução foi também sazonal, com aumento da atividade durante o início da estação de estiagem. Essas características ecológicas, e.g., raridade, hábito reofílico e hábito alimentar especializado, indica que $M$. paucisquamatus é vulnerável a mudanças ambientais, particularmente o barramento de rios. Considerando que atualmente três grandes barragens regulam e fragmentam esse trecho do rio Tocantins, a persistência da espécie encontra-se severamente ameaçada, demandando ações de conservação efetivas.

Keywords: Amazon, Conservation, Rare species, Rheophilic, River regulation.

\section{Introduction}

Mylesinus includes three valid species (Eschmeyer et al., 2015), distributed in river systems of the Amazon basin and central Brazil. One such species is Mylesinus paucisquamatus Jégu \& Santos, 1988, a small endemic fish from the rio Tocantins basin, usually found in riverine habitats such as rapids, waterfalls and streams (Jégu \& Santos, 1988; Santos et al., 2004). Some studies suggest that it is rare in terms of abundance and spatial occurrence (e.g., Marques et al., 2009; Miranda \& Mazzoni, 2009; Claro-Garcia \& Shibatta, 2013), currently listed as endangered (category "vulnerable") in the Brazilian official list of endangered species (Ministério do Meio Ambiente, Portaria $\left.n^{\circ} 445,2014\right)$. Although not evaluated by IUCN, the conservation status of this species is matter of great concern, because the construction of dams along the Tocantins caused extensive habitat losses and degradation (Araújo et al., 2013; Medeiros et al., 2014); populations may have been extirpated from some river sections.

Núcleo de Estudos Ambientais (NEAMB), Universidade Federal do Tocantins, Campus de Porto Nacional, Rua 3 Quadra 17 s/n Jardim dos Ipês, Caixa Postal 136, 77500-000 Porto Nacional, Tocantins, Brazil. (OBVJ) oscar@uft.edu.br (corresponding author), (CSA) agostinhocs@gmail.com, (FMP) fmpelicice@gmail.com 
Mylesinus paucisquamatus has been recorded in streams of the upper rio Tocantins basin (Miranda \& Mazzoni, 2003, 2009; Claro-Garcia \& Shibatta, 2013), and in the area where Serra da Mesa dam was constructed (Bartolette et al., 2012). In the lower rio Tocantins, the species apparently persists in streams adjacent to the Tucuruí reservoir (Ribeiro et al., 1995; Santos et al., 2004; Nogueira et al., 2010). It was also recorded in streams surrounding the Ecological Station of Serra Geral do Tocantins (Lima \& Caires, 2011; Nogueira et al., 2011) and in the main channel of the rio Tocantins (Lucinda et al., 2007; Soares et al., 2009). Although these studies indicate that $M$. paucisquamatus is widely distributed throughout the basin, no study investigated patterns of occurrence and abundance along the rio Tocantins mainstem. In addition, information on the ecology of $M$. paucisquamatus is scarce; no study has investigated the population structure, its feeding ecology or reproduction. It is known that a conspecific species, $M$. paraschomburgkii, feeds on aquatic plants, with predominance of Podostemaceae (Santos et al., 1997), so M. paucisquamatus may have a similar herbivorous diet.

The present study analyzed an extensive data set collected between 1998 and 2009, in order to investigate the spatial distribution, feeding and reproduction of $M$. paucisquamatus in a long stretch of the middle-upper rio Tocantins. Particularly, the objective of this study was to provide information about (i) population size structure, (ii) abundance patterns along the rio Tocantins and major tributaries, (iii) feeding and (iv) reproductive period. This information may contribute to set management plans to conserve this endangered species, primarily because the rio Tocantins is currently regulated and fragmented by several large hydropower dams (Araújo et al., 2013; Medeiros et al., 2014).

\section{Material and Methods}

Study area. The rio Tocantins is a tributary of the Amazon river system. Its headwaters are located in the central Brazilian plateau, and the river extends through $2,500 \mathrm{~km}$, discharging in the right bank of the lower rio Amazonas. The pluvial regime is seasonal (Mérona et al., 2010), with a marked wet (October and April) and dry season (May to September). Mean river discharge during the wet season is about $5.300 \mathrm{~m}^{3} \mathrm{~s}^{-1}$, while in the dry season it is about $750 \mathrm{~m}^{3} \mathrm{~s}^{-1}$ (Costa et al., 2003). The basin can be divided into distinct geomorphological regions (Ribeiro et al., 1995), with the upper and middle regions characterized by the presence of waterfalls and rapids, and the lower region characterized by lowlands and floodplains. At present, the main channel is regulated by seven large dams (Medeiros et al., 2014), which fragmented the fluvial course, stabilized the water level in the impounded areas and, consequently, changed the natural flow regime and habitat structure in some sections.
The present study was conducted along $200 \mathrm{~km}$ of the rio Tocantins in the transitional area between the upper and middle regions (e.g., Ribeiro et al., 1995), including the main channel of the rio Tocantins, the rio Paranã and other tributaries (Fig. 1). The area is currently under the influence of São Salvador and Peixe Angical hydropower dams, but all data analyzed in this work was collected before dam construction (see below).

Data sampling. We gathered information from three independent data sets, which covered 35 sampling sites during 96 months, between 1998 and 2009. These data sets are relative to monitoring programs carried out by the Núcleo de Estudos Ambientais (Universidade Federal do Tocantins, Brazil), which sampled the entire fish fauna to obtain information about the structure of local assemblages and populations. The present study, however, focused only on $M$. paucisquamatus data.

Data Set 1, included nine sites located near the confluence of the Paranã and Tocantins rivers (Fig. 1), sampled during 42 months between April 1998 and September 2001. Data Set 2, covered 10 sites distributed downstream and upstream from the confluence with the rio Paranã, including $56 \mathrm{~km}$ of this tributary (Fig. 1). These sites were sampled over 18 months, between October 2004 and January 2006. Currently, this river section is regulated by Peixe Angical hydropower dam, closed in January 2006, which formed a reservoir with $294 \mathrm{~km}^{2}$. Finally, Data Set 3, involved 17 sites located upstream from the previous sites, sampled during 18 months from August 2007 to February 2009. Currently, this region is regulated by São Salvador hydropower dam, closed in April 2009, which formed a reservoir with $104 \mathrm{~km}^{2}$.

Samples from each data set were taken monthly. A set of gill nets (12 mesh sizes: 2.4, 3, 4, 5, 6, 7, 8, 9, 10, 12, 14 and $16 \mathrm{~cm}$ between alternate knots), $20 \mathrm{~m}$ long, between 1.7 and $2.7 \mathrm{~m}$ high, was exposed for 24 hours in each site, and checked at 08:00 am, 04:00 pm and 10:00 pm. All individuals were identified, measured (standard length, SL, cm), weighted (total weight, TW, g), sexed and gutted. Phases of gonad maturation followed Brown-Peterson et al. (2011): Immature, Developing (which included Spawning Capable), Regressing and Regenerating. We combined Developing with Spawning Capable because $M$. paucisquamatus is a total spawner (Santos et al., 2004), so it is difficult to separate gonads that are developing from those ready to spawn. Gonad phases were assigned macroscopically considering characteristics of the gonads such as size, turgidity, irrigation, color and position in the abdominal cavity. In the case of ovaries, the presence and size of oocytes were also considered. We also weighted gonads (grams) for the calculation of the gonad-somatic index (Vazzoler, 1996). Stomach contents were sorted and identified under microscope and stereomicroscope to the lowest taxonomic level. We measured total volume of each resource using graduated cylinders. 


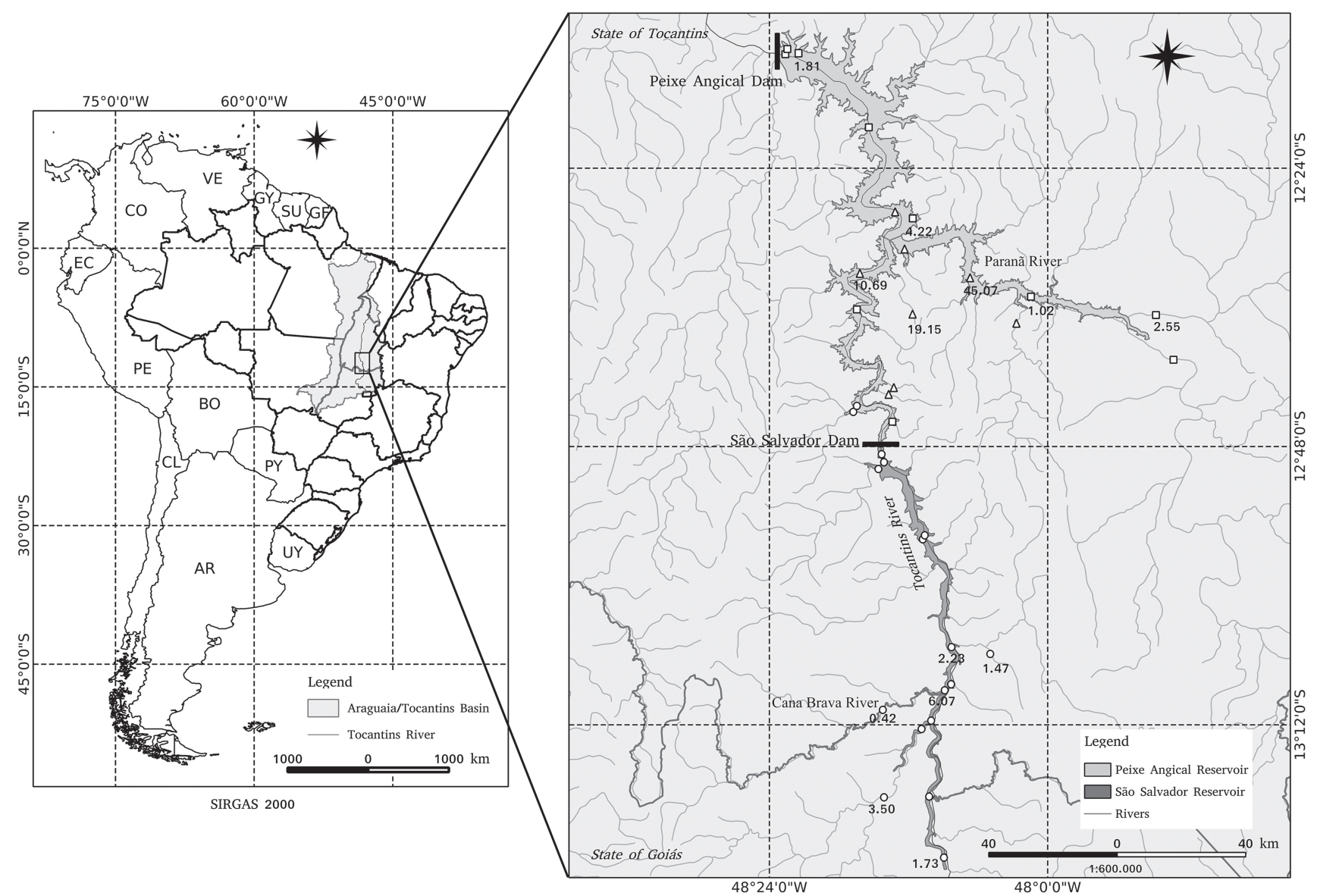

Fig. 1. Study area on the upper rio Tocantins, monitored between 1998 and 2009. Sampling sites of each data set are indicate by different symbols (Data Set $1=$ triangles; 2 = squares; $3=$ circles). Numbers near sampling sites are the relative abundance (\%) of Mylesinus paucisquamatus over the whole study period.

Data analysis. To investigate the spatial distribution of $M$. paucisquamatus, we calculated its relative abundance in each site ( $\%$, based on its total abundance), considering all data sets combined. Then, values were plotted on a map to illustrate spatial variation in fish abundance and occurrence along the main river channel and its tributaries. The rarity/ commonness of $M$. paucisquamatus within assemblages was determined considering its position in the rank of abundances, separately for each data set. To investigate if individuals are solitary or form shoals, we calculated the number of fish in each sampling event (site/month). Seasonal variation in fish abundance was calculated as relative abundance (\%) in different seasons, considering all data sets combined. Seasonal periods were defined following the seasonal pluviometric variation in different sections of the basin (Mérona et al., 2010): Wet (JanuaryMarch), Early Dry (April-June), Dry (July to September) and Early Wet (October-December). Finally, size structure was characterized by calculating the frequency of individuals in different classes of standard length ( $2 \mathrm{~cm}$ intervals) and body weight (100 $\mathrm{g}$ intervals).

Feeding and reproduction were investigated considering the complete data set. Species diet was characterized as occurrence and volume (\%) of each resource consumed. We also used a feeding index (IAi\%) to evaluated the importance of each resource, which combines volume and occurrence (Kawakami \& Vazzoler, 1980). To characterize the breeding period, we calculated the frequency of maturation phases and the mean gonad-somatic index (GSI) for each seasonal period, separately for males and females.

\section{Results}

Abundance and spatial distribution. Eighty-one individuals of $M$. paucisquamatus were captured between 1998 and 2009. The species occupied a low position in the rank of abundances, confirming its numerical rarity. On Data Set 1 (1998-2001), the species ranked $66^{\text {th }}$ among 273 species (61 individuals among 62,939 fishes). On Data Set 2 (20042006), the species was the $114^{\text {th }}$ most abundant among 217 species (10 individuals among 65,535 fishes). On Data Set 3 (2007-2009), the species ranked $60^{\text {th }}$ among 172 species (10 individuals among 18,909). Standard length ranged between 8.2 and $27 \mathrm{~cm}$, with higher frequency between 12 and $22 \mathrm{~cm}$ (Fig. 2a). Individual weight varied between 18.1 and $936.9 \mathrm{~g}$ (Fig. 2b), but most fish weighted between 100 and $300 \mathrm{~g}$. 

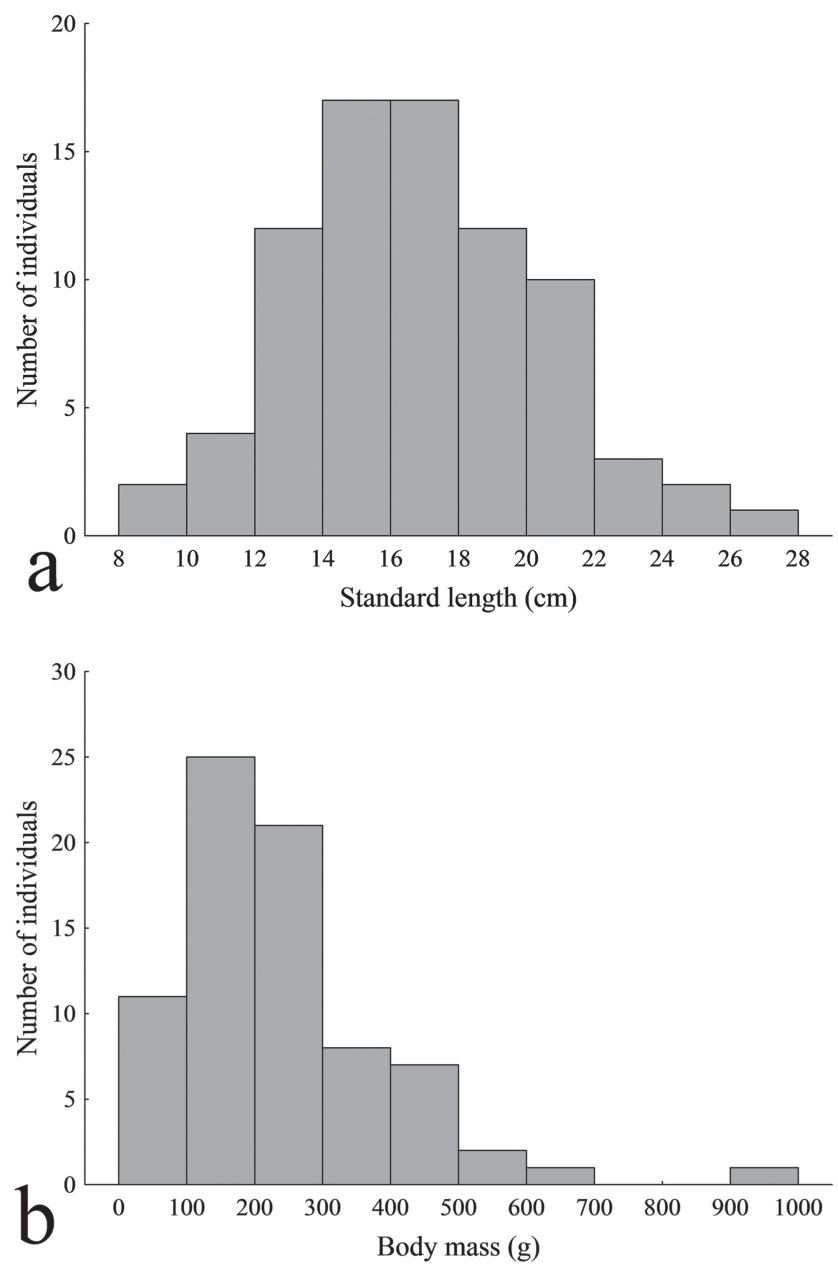

Fig. 2. Number of individuals of Mylesinus paucisquamatus within classes of standard length (a, centimeters) and total weight (b, grams), upper rio Tocantins.

We recorded the species in 13 out of 35 sampling sites. These sites were distributed along the entire river stretch, including the main channel and tributaries, but most captures occurred in the rio Paranã (c.a. $50 \%$ of all fish) and in sites near the confluence with the rio Tocantins (see Fig. 1). Early Dry and Dry periods showed higher fish abundance (Fig. 3). Most individuals were captured alone $(58 \%)$, while the remaining (42\%) was captured in small groups (two to five individuals).

Feeding. We analyzed 41 stomachs, obtained from fish with standard length ranging between 11.0 and $25.5 \mathrm{~cm}$. The diet showed a diversity of food resources, including invertebrates, filamentous algae and plant material (Table 1). However, plants were the main resource, especially periphytic bryophytes, which summed $68 \%$ of total volume and occurred in $70 \%$ of stomachs. Sediments were the second more important resource, summing $15 \%$ of total volume. Algae contributed less, but some groups were frequently consumed (e.g., Bacillariophyta and Zygnemaphycea). Invertebrates showed low volume and occurrence. The feeding index also indicated the importance of bryophytes, sediment and algae, indicating that M. paucisquamatus feeds on substrates, where they consume bryophytes and, accidentally, other resources.

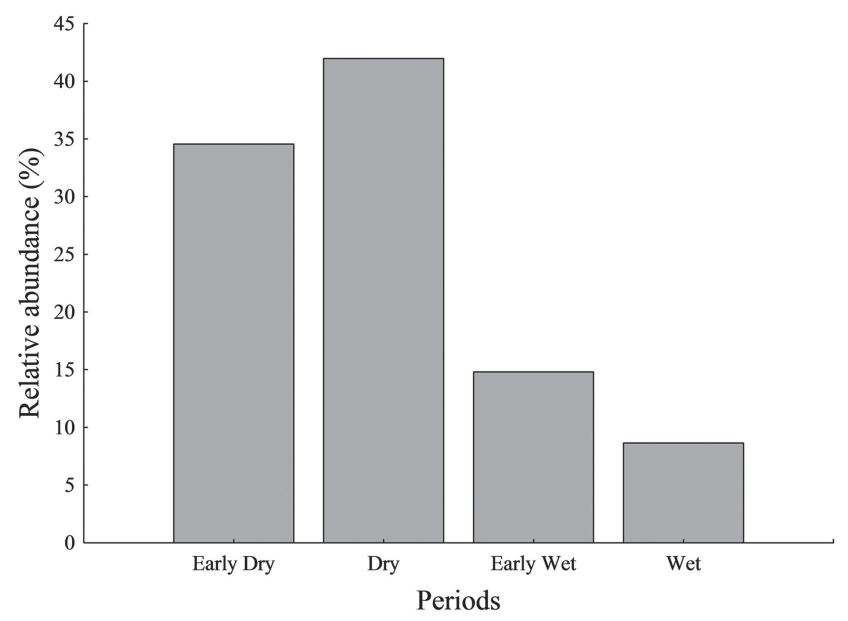

Fig. 3. Relative abundance (\%) of Mylesinus paucisquamatus among seasonal periods, considering all data sets combined, e.g., 81 individuals captured between 1998 and 2009, upper rio Tocantins.

Table 1. Food resources consumed by Mylesinus paucisquamatus in the upper rio Tocantins, summarized as relative Volume (\%), Occurrence (\%) and Feeding Index (IAi \%).

\begin{tabular}{|c|c|c|c|}
\hline Resources & $\begin{array}{l}\text { Volume } \\
(\%)\end{array}$ & $\begin{array}{l}\text { Occurrence } \\
(\%)\end{array}$ & $\begin{array}{c}\text { Feeding Index } \\
(\%)\end{array}$ \\
\hline Protozoa & 0.01 & 2.5 & $<0.01$ \\
\hline \multicolumn{4}{|c|}{ Invertebrates } \\
\hline Mites & 0.05 & 2.5 & $<0.01$ \\
\hline Bryozoa & 0.09 & 2.5 & $<0.01$ \\
\hline Diptera & 0.16 & 2.5 & $<0.01$ \\
\hline Ceratopogonidae (larvae) & 0.09 & 2.5 & $<0.01$ \\
\hline Trichoptera (larvae) & 0.19 & 2.5 & $<0.01$ \\
\hline Odonata & 0.4 & 2.5 & $<0.01$ \\
\hline Insect debris & 0.04 & 2.5 & $<0.01$ \\
\hline \multicolumn{4}{|c|}{ Algae } \\
\hline Bacillariophyta & 3.1 & 60 & 2.8 \\
\hline Chlorophycea & 0.93 & 20 & $<0.01$ \\
\hline Cyanophycea & 0.52 & 17.5 & $<0.01$ \\
\hline Ulotrichaceae & 0.07 & 5 & $<0.01$ \\
\hline Zygnemaphycea & 3.95 & 72.5 & 4.3 \\
\hline \multicolumn{4}{|c|}{ Plant material } \\
\hline Fruits & 4.96 & 2.5 & $<0.01$ \\
\hline Periphytic bryophytes & 68.45 & 72.5 & 74.7 \\
\hline Plant debris & 1.79 & 12.5 & $<0.01$ \\
\hline \multicolumn{4}{|c|}{ Inorganic material } \\
\hline Sediment & 15.21 & 75 & 17.2 \\
\hline
\end{tabular}


Reproduction. We inspected the gonads of 69 individuals, 43 males and 26 females (1.7:1 sex ratio). Most males were reproductive (Developing or Regressing), while most females were Regenerating; we did not capture immature fish. Overall, results indicate that reproduction takes place during dry months, between April and September. Males in reproduction (Developing or Regressing) were registered during the Early Dry and Dry periods (Fig. 4a), while reproductive females occurred mainly in the Early Dry period (Fig. 4b). Females showed high mean GSI during the Early Dry period (Fig. 4b), while males showed lower values over the seasons (Fig. 4a).
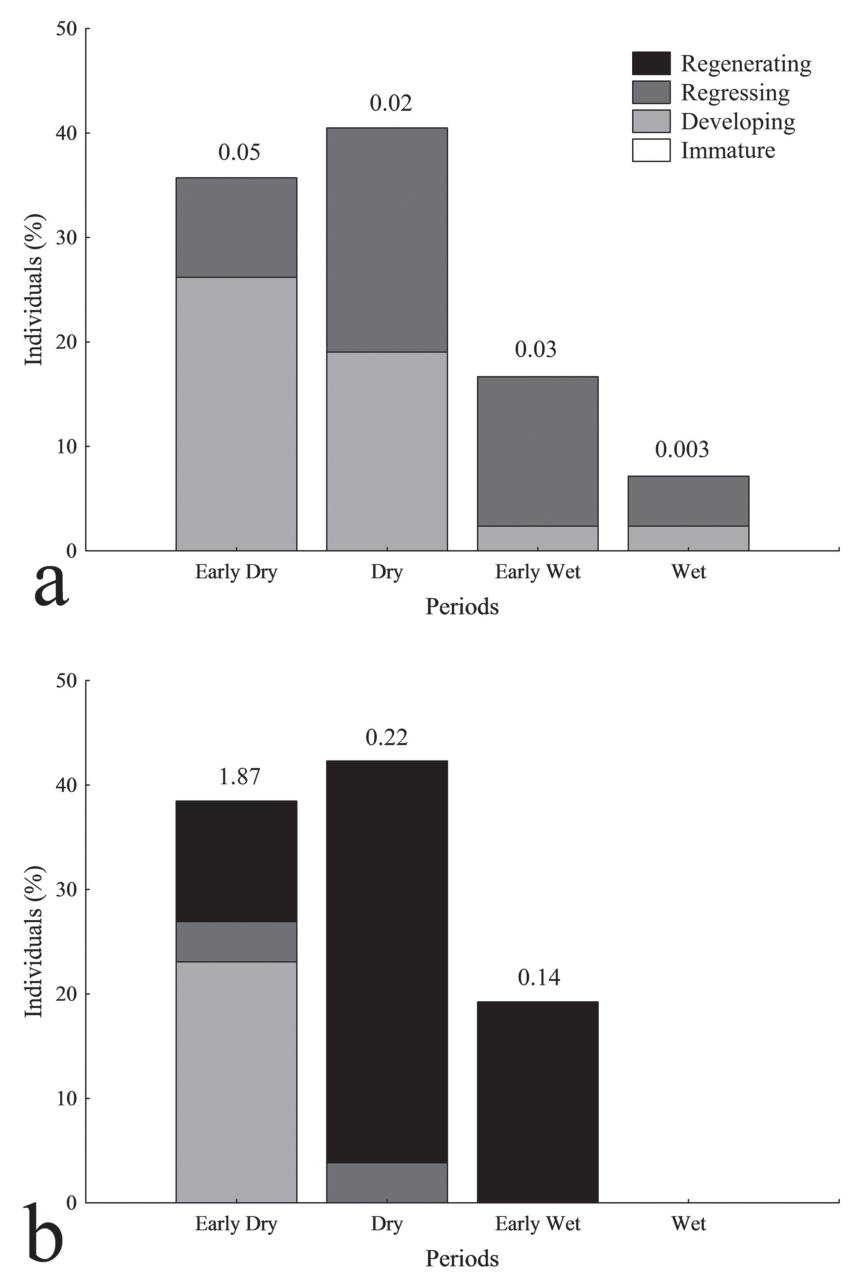

Fig. 4. Percentage of reproductive phases of Mylesinus paucisquamatus among seasonal periods, for males (a) and females (b), upper rio Tocantins. Numbers above bars are the mean gonad-somatic index (GSI, \%) for each period.

Many individuals in reproduction (64\%) were captured in the rio Paranã and its tributaries (e.g., Traçadal stream and rio Palmas), while the remainder was recorded in the rio Tocantins and smaller tributaries. The absence of immatures in our samples suggests that first maturation occurs at sizes smaller than $8.2 \mathrm{~cm}$ SL for females and 11 $\mathrm{cm}$ for males.

\section{Discussion}

This study investigated the ecology of $M$. paucisquamatus in the middle-upper rio Tocantins basin, an endemic fish currently threatened with extinction (Rosa \& Lima, 2008). Based on an extensive data set that included 35 sites sampled between 1998 and 2009, we observed that M. paucisquamatus is a rare species living in small groups, distributed sparsely along this $200 \mathrm{~km}$ section of the rio Tocantins. We confirmed its numerical rarity because only 81 individuals were captured over a decade of field sampling. Other studies have also reported low abundance of M. paucisquamatus within fish assemblages (Marques et al., 2009; Miranda \& Mazzoni, 2009; Claro-Garcia \& Shibatta, 2013). Moreover, we also observed spatial rarity considering that the species occurred in 13 out of 35 sites, and most captures occurred in some specific sites, probably linked to the distribution of preferential habitats. Mylesinus paucisquamatus was captured mainly in the Tocantins, Paranã and Cana Brava, especially near confluence zones. These results support the idea that this species is rheophilic and rare, with small populations distributed over restricted sites along the mainstem and tributaries.

Despite the low total catch, we observed seasonal variation in abundance, with higher values during drier months. This variation is probably associated with seasonal movements between the main channel (Tocantins and Paranã rivers) and smaller tributaries. The rainfall regime has well-defined wet and dry seasons in this watershed (Ribeiro et al., 1995; Miranda \& Mazzoni, 2009; Mérona et al., 2010). During dry months, water flow is significantly reduced in some tributaries and fish may find refuge at lower reaches, e.g., the main channel and river confluences. During the wet season, increased river connectivity must enhance fish dispersal across the river network. The interaction between water level and resource availability (e.g., exposition and submersion of bryophytes) may also induce movements, considering that fish have to find submerged beds during the dry season. We also highlight that this study did not sample small streams, but other studies have recorded M. paucisquamatus in these environments (Lima \& Caires, 2011; Nogueira et al., 2011). Therefore, future studies must elucidate its distribution, environmental preference (e.g., streams, river channel) as well as the use of different riverine habitats along the year. It is worth noting, however, that several large dams currently regulate the flow regime of the rio Tocantins and some tributaries. These impoundments affected fish populations and assemblage structure (Pelicice et al., 2009; Araújo et al., 2013; Medeiros et al., 2014), therefore, it is likely that the distribution of $M$. paucisquamatus has been also affected. In the area impacted by Tucuruí dam, for example, the species apparently persists in streams adjacent to the reservoir (Ribeiro et al., 1995; Santos et al., 2004; Nogueira et al., 2010), which may work as refuge after the loss of lotic habitats. In the upper-middle rio Tocantins, we 
believe that populations are now restricted to free-flowing remaining areas, which still preserve lotic conditions, shallow areas, bedrocks and feeding sites, such as the rio Paranã and the long section between Peixe Angical dam and Lajeado reservoir.

The feeding of $M$. paucisquamatus is intimately related to the life in running waters, as the species consumed primarily periphytic bryophytes. In aquatic environments, these plants usually live in lotic habitats anchored in substrates such as rocks and logs (Câmara \& Leite, 2005; Peralta et al., 2008). The feeding site, therefore, must be shallow lotic areas (e.g. rapids) where it feeds upon mosses in rocks and other substrates. The intake of other resources such as sediment, filamentous algae and aquatic invertebrates is probably accidental during the removal of bryophytes, considering that these resources summed lower volume/occurrence. Future studies must determine the importance of these secondary resources to the energy budget, but our results suggest that $M$. paucisquamatus is specialized to consume periphytic bryophytes. This fish has robust teeth and mouth structure, with elongated mandible and maxilla, which probably facilitate the removal of vegetation from substrates. Other species of pacu have similar feeding behavior, consuming Podostemaceae that grow in rapids and other lotic habitats (Santos et al., 1997). The specialization in this type of resource (i.e., periphytic bryophytes) must have ecological benefits such as low competition, since few Neotropical fishes consume aquatic plants (Hahn \& Fugi, 2008). This specialization, however, makes $M$. paucisquamatus vulnerable to habitat loss, especially because rapids disappear after river regulation. Indeed, many rapids and waterfalls were lost from the rio Tocantins after the construction of large dams, which may have reduced the extent of feeding sites.

Mylesinus paucisquamatus showed seasonal reproduction, with greater effort (GSI) in the beginning of the dry season, between April and June. This behavior diverges from the main reproductive pattern exhibited by other Neotropical species, where fishes reproduce during the rainy season (see chapters in Carolsfeld et al., 2003), when early life forms have access to nursery grounds (e.g., floodplains, backwaters, lagoons). In the upper rio Tocantins, for example, Medeiros et al. (2009) reported high reproductive activity of the fish fauna during wet months (December to February). The inverse pattern, e.g. reproduction during drier months, is a typical behavior of stream fishes, which take advantage of the more predictable flow variation caused by low precipitation (Winemiller et al., 2008; Abilhoa et al., 2011), as a means of reducing the loss of eggs and larvae. The present study cannot confirm if M. paucisquamatus uses streams to spawn, but the absence of immature fish in our samples indicates that smaller fish use other habitats for some period of time, probably smaller water bodies. Considering that the upper rio Tocantins runs through the valley and lowland areas are naturally scarce (Ribeiro et al., 1995), recruitment dynamics may involve spawning in small tributaries where larvae and juveniles grow, and migration to main channels as they attain larger sizes and sexual maturity; a pattern analogous to other embedded rivers (Ávila-Simas et al., 2014). Future studies must further investigate these dynamics to identify spawning and growing sites, but our results indicate that adults live in the main channel while early life forms and juveniles grow in other, yet unknown, habitats.

In conclusion, M. paucisquamatus is an endangered fish in a scenario of deep environmental changes, which includes the expansion of large-scale agriculture and hydropower development (Costa et al., 2003; Coe et al., 2009; Castello et al., 2013). Although our study has not investigated the influence of impoundments on $M$. paucisquamatus, almost all fish were captured between 1998 and 2001 (Data Set 1), before the construction of several dams: Lajeado (closed in 2002), Peixe Angical (2006) and São Salvador (2010). It is very likely, therefore, that these dams affected the distribution, demography and population structure of this species. We emphasize that this species is naturally rare (e.g., abundance and spatial distribution), rheophilic and with a specialized diet, ecological traits that make it vulnerable to environmental changes. The only conservation measure in the basin is the fishing closure that takes place between November and March, to protect fish reproduction. However, this measure does not benefit M. paucisquamatus, considering that this fish reproduces in a different period. Ultimately, the conservation of this species will depend on the preservation of lotic stretches, riverine habitats and the natural flow regime, at least in some sections (Pelicice et al., 2015). The Paranã and Cana Brava rivers, for example, may provide essential habitats because these tributaries are free flowing. The same is valid for the $230 \mathrm{~km}$ stretch between Peixe Angical dam and Lajeado reservoir, which contains large tributaries and small wetlands (Pelicice \& Agostinho, 2012). Conservation efforts, therefore, must give high priority to the conservation of remnant lotic sites. The species is currently listed as "vulnerable" by the Brazilian list of endangered species (Rosa \& Lima, 2008), but the absence of official conservation plans, together with extensive habitat losses caused by hydropower development, indicate that the persistence of populations in the middle-upper rio Tocantins will constitute an enormous challenge.

\section{Acknowledgements}

We thank anonymous reviewers for all comments and corrections, colleagues from the Núcleo de Estudos Ambientais (NEAMB - Universidade Federal do Tocantins) for their assistance in field, laboratory work and Mônica Pacheco de Araújo (PPG Ecologia de Ecótonos - UFT) for drawing the map. We also thank Furnas Centrais Elétricas S.A., Enerpeixe S.A. and Companhia Energética São Salvador (CESS) for financial support. CNPq provided a research grant for FMP. 


\section{References}

Abilhoa, V., R. R. Braga, H. Bornatowski \& J. R. S. Vitule. 2011. Fishes of the Atlantic Rain Forest streams: ecological patterns and conservation. Pp. 259-282. In: Grillo, O. \& G. Venora (Eds.). Changing Diversity in Changing Environment. Croatia, Intech.

Araújo, E. S., E. E. Marques, I. S. Freitas, A. L. Neuberger, R. Fernandes \& F. M. Pelicice. 2013. Changes in distance decay relationships after river regulation: similarity among fish assemblages in a large Amazonian river. Ecology of Freshwater Fish, 22: 543-552.

Ávila-Simas, S., D. A. Reynalte-Tataje \& E. Zaniboni Filho. 2014. Pools and rapids as spawning and nursery areas for fish in a river stretch without floodplains. Neotropical Ichthyology, 12: 611-622.

Bartolette, R., R. Souza-Lima, C. A. A. Figueiredo, D. F. Moraes Júnior. \& E. P. Caramaschi. 2012. Composição taxonômica da ictiofauna da área da UHE Serra da Mesa. Pp. 53-90. In: Mazzoni, R., E. P. Caramaschi \& R. Iglesias-Rios (Eds.). Usina Hidrelétrica de Serra da Mesa: 15 anos de estudos da ictiofauna do Alto Tocantins. Rio de Janeiro, Furnas.

Brown-Peterson, N. J., D. M. Wyanski, F. Saborido-Rey, B. J. Macewicz \& S. K. Lowerre-Barbieri. 2011. A standardized terminology for describing reproductive development in fishes. Marine and Coastal Fisheries: Dynamics, Management, and Ecosystem Science, 3: 52-70.

Câmara, P. E. \& R. N. Leite. 2005. Bryophytes from Jalapão, state of Tocantins, northern Brazil. Tropical Bryology, 26: 23-29.

Carolsfeld, J., B. Harvey, C. Ross \& A. Baer (Eds.). 2003. Migratory fishes of South America: biology, fisheries and conservation status. Ottawa, World Fisheries Trust, The World Bank, 372p.

Castello, L., D. G. McGrath, L. L. Hess, M. T. Coe, P. A. Lefebvre, P. Petry, M. N. Macedo, V. F. Renó \& C. C. Arantes. 2013. The vulnerability of Amazon freshwater ecosystems. Conservation Letters, 6: 217-229.

Claro-García, A. \& O. A. Shibatta. 2013. The fish fauna of streams from the upper rio Tocantins basin, Goiás State, Brazil. Check List, 9: 028-033.

Coe, M. T., M. H. Costa \& B. S. Soares-Filho. 2009. The influence of historical and potential future deforestation on the stream flow of the Amazon river - land surface processes and atmospheric feedbacks. Journal of Hydrology, 369: 165-174.

Costa, M. H., A. Botta \& J. A. Cardille. 2003. Effects of large-scale changes in land cover on the discharge of the Tocantins River, Southeastern Amazonia. Journal of Hydrology, 283: 206-217.

Eschmeyer, W. N., R. Fricke \& R. van der Laan. 2015. Catalog of fishes: genera, species, references. Available from: http:// researcharchive.calacademy.org/research/ichthyology/ catalog/fishcatmain.asp. (23 January 2015).

Hahn, N. S. \& R. Fugi. 2008. Environmental changes, habitat modifications and feeding ecology of freshwater fish. Pp. 3665. In: Cyrino, J. E. P., D. P. Bureau \& B. G. Kapoor (Eds.). Feeding and digestive functions of fishes. New Hampshire, Science.
Jégu, M. \& G. M. Santos. 1988. Une nouvelle espèce du genre Mylesinus (Pisces, Serrasalmidae), M. paucisquamatus, décrite du bassin du rio Tocantins (Amazonie, Brésil). Cybium, 12: 331-341.

Kawakami, E. \& G. Vazzoler. 1980. Método gráfico e estimativa de índice alimentar aplicado no estudo de alimentação de peixes. Boletim do Instituto Oceanográfico, 29: 205-207.

Lima, F. C. T. \& R. A. Caires. 2011. Peixes da Estação Ecológica Serra Geral do Tocantins, bacias dos rios Tocantins e São Francisco, com observações sobre as implicações biogeográficas das "águas emendadas” dos rios Sapão e Galheiros. Biota Neotropica, 11: 231-249.

Lucinda, P. H. F., I. S. Freitas, A. B. Soares, E. E. Marques, C. S. Agostinho \& R. J. Oliveira. 2007. Fish, Lajeado Reservoir, rio Tocantins drainage, State of Tocantins, Brazil. Check List, 3: 70-83.

Marques, E. E., R. M. Silva \& D. S. Silva. 2009. Variações espaciais na estrutura das populações de peixes antes e após a formação do reservatório de Peixe Angical. Pp. 51-57. In: Agostinho, C. S., F. M. Pelicice \& E. E. Marques (Orgs.). Reservatório de Peixe Angical: bases ecológicas para o manejo da ictiofauna. São Carlos, RiMa.

Medeiros, E. R., A. L. Neuberger. \& C. S. Agostinho. 2009. Variações sazonais na atividade reprodutiva de peixes na área de influência do reservatório de Peixe Angical. Pp. 6976. In: Agostinho, C. S., F. M. Pelicice \& E. E. Marques (Orgs.). Reservatório de Peixe Angical: bases ecológicas para o manejo da ictiofauna. São Carlos, RiMa.

Medeiros, E. R., F. M. Pelicice, C. S. Agostinho \& E. E. Marques. 2014. Short-term changes in energy allocation by Hemiodontidae fish after the construction of a large reservoir (Lajeado Dam, Tocantins River). Neotropical Ichthyology, 12: 649-658.

Mérona, B., A. A. Juras, G. M. Santos \& I. H. A. Cintra. 2010. Os peixes e a pesca no baixo rio Tocantins: vinte anos depois da UHE Tucuruí. Brasília, Eletronorte, 265p.

Miranda, J. C. \& R. Mazzoni. 2003. Composição da ictiofauna de três riachos do alto rio Tocantins - GO. Biota Neotropica, 3: 1-11.

Miranda, J. C. \& R. Mazzoni. 2009. Estrutura e persistência temporal da comunidade de peixes de três riachos do Alto Rio Tocantins, GO. Biota Neotropica, 9: 71-78.

Nogueira, C., P. A. Buckup, N. A. Menezes, O. T. Oyakawa, T. P. Kasecker, M. B. Ramos Neto, \& J. M. C. da Silva. 2010. Restricted-range fishes and the conservation of Brazilian freshwaters. PLoS ONE, 5: 10p.

Nogueira, C. C., M. N. Ferreira, R. S. Recoder, A. P. Carmignotto, P. H. Valdujo, F. C. T. Lima, R. Gregorin, L. F. Silveira \& M. T. Rodrigues. 2011. Vertebrados da Estação Ecológica Serra Geral do Tocantins: faunística, biodiversidade e conservação no Cerrado brasileiro. Biota Neotropica, 11: 329-338.

Pelicice, F. M. \& C. S. Agostinho. 2012. Deficient downstream passage through fish ladders: the case of Peixe Angical Dam, Tocantins River, Brazil. Neotropical Ichthyology, 10: 705-713. 
Pelicice, F. M., A. Akama, R. J. Oliveira \& D. S. Silva. 2009. Padrões espaciais e temporais na distribuição da ictiofauna, antes e após a formação do reservatório de Peixe Angical. Pp. 29-39. In: Agostinho, C. S., F. M. Pelicice \& E. E. Marques (Orgs.). Reservatório de Peixe Angical: bases ecológicas para o manejo da ictiofauna. São Carlos, RiMa.

Pelicice, F. M., P. S. Pompeu \& A. A. Agostinho. 2015. Large reservoirs as ecological barriers to downstream movements of Neotropical migratory fish. Fish and Fisheries, 16: 697-715.

Peralta, D. F., J. Bordin \& O. Yano. 2008. New mosses records (Bryophyta) for Goiás and Tocantins states, Brazil. Acta Botanica Brasilica, 22: 834-844.

Ribeiro, M. C. L. B., M. Petrere Júnior \& A. A. Juras. 1995. Ecological integrity and fisheries ecology of the AraguaiaTocantins river basin, Brazil. Regulated Rivers: Research \& Management, 11: 325-350.

Rosa, R. S. \& F. C. T. Lima. 2008. Os peixes brasileiros ameaçados de extinção. v. 2, Pp. 8-285. In: Machado, A. B. M., D. M. Drummond \& A. P. Paglia (Eds.). Livro vermelho das espécies ameaçadas de extinção. Brasília, MMA.

Santos, G. M., B. Mérona, A. A. Juras \& M. Jégu. 2004. Peixes do baixo rio Tocantins: 20 anos depois da Usina Hidrelétrica Tucuruí. Brasília, Eletronorte, 203p.
Santos, G. M., S. S. Pinto \& M. Jégu. 1997. Alimentação do pacucana, Mylesinus paraschomburgkii (Teleostei, Serrasalmidae) em rios da Amazônia brasileira. Revista Brasileira de Biologia, 57: 311-315.

Soares, A. B., F. M. Pelicice, P. H. F. Lucinda, A. Akama \& C. S. Agostinho. 2009. Diversidade de peixes na área de influência da barragem de Peixe Angical, antes e após a formação do reservatório. Pp. 15-27. In: Agostinho, C. S., F. M. Pelicice \& E. E. Marques (Orgs.). Reservatório de Peixe Angical: bases ecológicas para o manejo da ictiofauna. São Carlos, RiMa.

Vazzoler, A. E. A. M. 1996. Biologia da reprodução de peixes teleósteos: teoria e prática. Maringá, Eduem, 169p.

Winemiller, K. O., A. A. Agostinho \& E. P. Caramaschi. 2008. Fish ecology in tropical streams. Pp. 107-146. In: Dudgeon, D. (Ed.). Tropical stream ecology. Amsterdam, Academic Press.

Submitted August 21, 2015

Accepted March 29, 2016 by Norma Hahn 